\title{
Frequency of Microvascular Complications in the Early Phase of Diabetes Mellitus Type 2 with Albuminuria
}

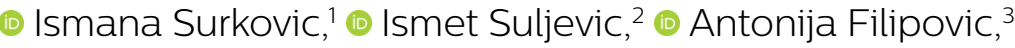 \\ Maida Turan, ${ }^{3}$ (1) Omer Suljevic ${ }^{3}$
}

${ }^{1}$ University Clinical Center Sarajevo,
Clinic for Endocrinology, Diabetes
and Metabolism Diseases,
Sarajevo, BIH
${ }^{2}$ University Clinical Center Sarajevo,
Clinic for Anesthesiology and
Resuscitation, Sarajevo, BIH
3Public Institution Health Center of
Sarajevo Canton, Sarajevo, BiH

Submitted: 08.06.2020 Accepted: 11.07.2020

Correspondence: Ismana Surkovic, Bolnicka 2571000 Sarajevo - Bosnia and Herzegovina

E-mail: ismana_surkovic@yahoo.com

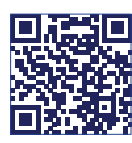

Keywords: Complications; diabetes; nephropathy; neuropathy; retinopathy.

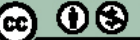
This work is licensed under a Creative Commons Attribution-NonCommercial 4.0 International License.

\begin{abstract}
Objective: Diabetes Mellitus Type 2 (DM2) is characterized by varying degrees of insulin resistance, impaired insulin secretion, and increased glucose production. Some people with DM2 have more complications such as nephropathy, retinopathy, and neuropathy. The earliest stage of renal impairment occurs with prolonged microalbuminuria. This study aimed to determine the incidence of the most common microvascular complications in DM2 patients.

Methods: We retrospectively evaluated the data of 126 patients who had undergone treatment in 2014. It includes anamnesis, laboratory, and physical examination data from the patient histories. All patients with early stage DM2 were separated into two groups based on the presence of albuminuria: Group I - macroalbuminuria and Group II - microalbuminuria $(<300 \mathrm{mg})$. Analysis and statistical processing of the collected data were performed to evaluate microvascular complications and determine the incidence of albuminuria in the studied population.
\end{abstract}

Results: The prevalence of macroalbuminuria was $60.3 \%$ (76 patients). In both groups, as in the total sample, the frequency of women was higher $(57.9 \%)$. The prevalence of macroalbuminuria was strongly influenced by age ( $\geq 65$ years) of the patients $(72.4 \%$, average age $=$ $69.8 \pm$ II.I years). Microalbuminuria has been proven to be an extremely significant marker for development of microvascular complications in DM2 (retinopathy $39.5 \%$, neuropathy $52.6 \%$, and nephropathy 54\%).

Conclusion: Early diagnosis of microvascular complications and an adequate therapeutic approach is needed to prevent disability. Therefore, it is important to introduce the screening for the presence of microalbuminuria in practice, which will identify patients at increased risk of developing microvascular complications.

\section{INTRODUCTION}

Diabetes Mellitus Type 2 (DM2) is caused by a combination of insulin resistance and inadequate insulin compensatory secretory response. Chronic hyperglycemia causes dysfunction of various organs, especially the eyes, kidneys, nerves, heart, and blood vessels. A level of hyperglycemia that can cause pathological and functional changes in different organs, but without clinical symptoms, can be present for a long period of time before diabetes is detected. Epidemiological studies suggest that some signs of DM2, such as microalbuminuria, may occur up to ten years before diagnosis. Microalbuminuria is also a sign of increased cardiovascular morbidity and mortality in patients with diabetes, essential hypertension, and in the general population, as it occur with insulin resistance, atherogenic dyslipidemia, and central obesity. Albuminuria also indicates vascular permeability disorder, which is caused by generalized endothelial dysfunction. ${ }^{[1-3]}$ On average, diabetic retinopathy occurs after 8-10 years of DM2. It engages both eyes and leads to blindness in the final stage. ${ }^{[4]}$ Diabetic neuropathy is the most common complication of DM2, with a prevalence of $1.4-11.6 \%$ at time of diagnosis and after 25 years. About $50 \%$ of DM2 patients have some form of diabetic neuropathy. ${ }^{[5,6]}$ The main cause of death and disability in patients with DM2 is due to kidney disease. About $50 \%$ of cases of terminal kidney disease in the United States and other developed countries account for diabetic nephropathy. This complication develops in 15-65\% of cases with DM2. Early detection of diabetic nephropathy is based on determination of albumin in urine. Qualitative albuminuria test strip method can detect daily excretion of albumin in excess of $300 \mathrm{mg}$. Microalbuminuria indicates the excretion of small but pathological amounts of albumin in 
urine at an interval of $30-300 \mathrm{mg} / 24 \mathrm{~h}$. The presence of permanent microalbuminuria indicates an early stage of renal impairment in diabetes, which precedes the clinical manifestation of nephropathy. ${ }^{[7]}$

\section{MATERIALS AND METHODS}

The study is retrospective, clinical, and comparative. It was conducted at the Clinic for Endocrinology, Diabetes and Metabolism Diseases, University Clinical Center in Sarajevo, $\mathrm{BiH}$. The study included 126 patients $(53$ men and 73 women). The study involves the analysis of anamnesis, laboratory, and physical examination data from history of patient with DM2 in 2014. All patients with early stage DM2 were separated into two groups based on the presence of albuminuria: Group I - patients with macroalbuminuria; and Group II - patients with microalbuminuria (<300 mg). The presence of microvascular complications was recorded from the findings of appropriate specialists. Patients who had DM2 for more than 5 years were excluded from the study. In this study, we analyzed gender, age, body mass index (BMI), hemoglobin Alc (HbAlc, target values $\leq 7 \%$ ), fasting blood glucose (FBG, target value $<7.0$ $\mathrm{mmol} / \mathrm{L}$ ), albuminuria, and complications of underlying disease (retinopathy, neuropathy, and nephropathy).

\section{Statistical analysis}

Results of the study were documented, statistically analyzed, and presented graphically by number of cases, percentages, and arithmetic mean $(X)$ with standard deviation (SD). Chi-Square $\left(\chi^{2}\right)$ test and Student $t$ test were used to test for differences between the observed patient groups, depending on the data type. Test results with $p$ value $<0.05$ or $95 \%$ confidence level were considered statistically significant. The analysis was performed using SPSS Statistics for Windows, version 20.0 (SPSS Inc., Chicago, III., USA) and Microsoft Excel 2007.

\section{RESULTS}

The study included 126 patients. Analysis of the gender distribution indicates a higher representation of women $(n=73 ; 57.9 \%)$ than men $(n=53 ; 42.1 \%)$.

Analysis of sex and age distribution shows that the average age of the study population is 66.5 years, with a SD of 12.7. In the total sample, patients $\geq 65$ years of age ( $57.9 \%)$ were the most represented, such that the women were significantly older $(65.3 \%$ was $\geq 65$ years old) when compared to men ( $34.7 \%$ was $\geq 65$ years old). This is also evident in the mean values of age for men $(63.9 \pm 14$. I years) and women $(68.3 \pm$ I I.5 years) (Table I).

Analysis of the gender representation of the respondents revealed that women, in the same percentage ratio, were more represented in the total sample and both groups of patients with macroalbuminuria $(57.9 \%)$. In the group of patients with microalbuminuria, women were also more prevalent than men ( $58 \%$ vs. $42 \%)$, but without a statistically significant difference $(p>0.05)$ (Table 2$)$.

Analysis of the distribution of respondents by age group indicates that the most represented patients are older than 65 years (59.6\%). Higher prevalence of patients older than 65 years was in the patients' group with macroalbuminuria $(72.4 \%)$, as compared to the patients' groups with microalbuminuria ( $<300 \mathrm{mg})(40 \%)$, with a statistically significant difference $(p<0.05)$. This is supported by analysis of the mean, according to which patient in the total sample had an average age of $66.5 \pm 12.7$ years and by the fact that patients with macroalbuminuria were older with an average age of $69.8 \pm \mathrm{II} . \mathrm{I}$ years, as compared with patients with microalbuminuria, where the mean age was $61.4 \pm 13.5$ years, with a statistically significant difference $(\mathrm{p}<0.05)$ (Table 3).

$\mathrm{BMI}$ analysis shows that, in the overall sample, the highest number of patients is represented in the BMI category $\geq 30 \mathrm{~kg} / \mathrm{m}^{2}$ (obesity, $35.7 \%$ ). This prevalence is higher in the group of patients with microalbuminuria (<300 mg) (44\%); whereas, in the group of patients with macroalbuminuria, it was more prevalent in overweight patients (35.5\%) and normal patients $(28.9 \%)$, but with no statistically significant difference $(p>0.05)$ (Table 4).

Analysis of mean fasting glycemic values showed that these values were higher in patients with microalbuminuria (I $\pm 3.9 \mathrm{mmol} / \mathrm{L})$, but with no statistically significant difference $(p>0.05)$. There is also no statistical significance for differences in mean $\mathrm{HbAlc}$, with these values being higher in patients with macroalbuminuria (9.6\%) (Table 5).

In the macroalbuminuria group, retinopathy was found in $39.5 \%$ of patients, as compared to the microalbuminuria group, where retinopathy was found in $2 \%$ of patients, with a statistically significant difference $(p<0.05)\left(X^{2}=22.83 I\right)$ $(p=0.000002)$.

Table I. Shows the number and percentage values of patients included in the study by age group by gender

\begin{tabular}{lccccr}
\hline Gender & \multicolumn{5}{c}{ Age (years) } \\
\cline { 2 - 6 } & $\mathbf{2 5 - 4 4}$ & $\mathbf{4 5 - 6 4}$ & $\mathbf{2 6 5}$ & Total & Mean (SD) \\
\hline Male, n (\%) & $7(\mathbf{7 7 . 8 )}$ & $20(47.6)$ & $26(34.7)$ & $53(42.1)$ & $63.9(14.1)$ \\
Female, n (\%) & $2(22.2)$ & $22(52.4)$ & $49(65.3)$ & $73(57.9)$ & $68.3(11.5)$ \\
Total, n (\%) & $9(7.2)$ & $42(33.3)$ & $75(59.5)$ & $126(100.0)$ & $66.5(12.7)$ \\
\hline
\end{tabular}

$\chi^{2}=6.926 ; p=0.0313 . S D:$ Standard deviation 
Table 2. Gender representation of respondents in the follow-up groups

\begin{tabular}{lllc}
\hline & Group I & Group II & Total \\
\hline $\begin{array}{cccc}\text { Gender, n (\%) } \\
\text { Male }\end{array}$ & $32(42.1)$ & $21(42.0)$ & $53(42.1)$ \\
$\quad$ Female & $44(57.9)$ & $29(58.0)$ & $73(57.9)$ \\
Total, n (\%) & $76(60.3)$ & $50(39.7)$ & $126(100.0)$ \\
\hline
\end{tabular}

Group I: Patients with macroalbuminuria; Group II: Patients with microalbuminuria; $\chi^{2}=0.0001 ; p=0.9907$.

Table 3. Distribution of patients by age in the follow-up groups

\begin{tabular}{cccc}
\hline & Group I & Group II & Total \\
\hline Age (years), n (\%) & & & \\
$25-44$ & $3(3.9)$ & $6(12)$ & $9(7.1)$ \\
$45-64$ & $18(23.7)$ & $24(48)$ & $42(33.3)$ \\
$\geq 65$ & $55(72.4)$ & $20(40)$ & $75(59.6)$ \\
Total, n (\%) & $76(60.3)$ & $50(39.7)$ & $126(100.0)$ \\
\hline
\end{tabular}

Group I: Patients with macroalbuminuria; Group II: Patients with microalbuminuria; $\chi^{2}=13.3958 ; p=0.001234$.

Table 4. Distribution of patients by BMI values in the monitored groups

\begin{tabular}{cccc}
\hline & Group I & Group II & Total \\
\hline BMI $\left(\mathrm{kg} / \mathrm{m}^{2}\right), \mathrm{n}(\%)$ & & & \\
$<18.5 \mathrm{~kg} / \mathrm{m}^{2}$ & $4(5.3)$ & $2(4.0)$ & $6(4.8)$ \\
$18.5-24.9 \mathrm{~kg} / \mathrm{m}^{2}$ & $22(28.9)$ & $13(26.0)$ & $35(27.8)$ \\
$25-29.9 \mathrm{~kg} / \mathrm{m}^{2}$ & $27(35.5)$ & $13(26.0)$ & $40(31.7)$ \\
$>30 \mathrm{~kg} / \mathrm{m}^{2}$ & $23(30.3)$ & $22(44.0)$ & $45(35.7)$ \\
Total & $76(60.3)$ & $50(39.7)$ & $126(100.0)$ \\
\hline
\end{tabular}

Group I: Patients with macroalbuminuria; Group II: Patients with microalbuminuria; $\chi^{2}=2.651 ; p=0.4486$. BMl: Body mass index.

In the macroalbuminuria group, 40 patients $(52.6 \%)$ had neuropathy, while in the microalbuminuria group, 5 patients $(10.0 \%)$ had neuropathy, with a statistically significant difference $(p<0.05)\left(X^{2}=23.874\right)(p=0.00000 I)$.

In the macroalbuminuria group, 4 I patients $(54.0 \%)$ had positive findings of nephropathy; whereas, in the microal-
Table 6. Prevalence of patients with macroalbuminuria and microalbuminuria according to existing (recorded) retinopathy, neuropathy and nephropaty

\begin{tabular}{lccc}
\hline $\begin{array}{l}\text { Microvascular } \\
\text { complication }\end{array}$ & Group I & Group II & Total \\
\hline $\begin{array}{l}\text { Retinopathy, n (\%) } \\
\quad \text { Negative }\end{array}$ & $46(60.5)$ & $49(98.0)$ & $95(75.4)$ \\
$\quad \begin{array}{l}\text { Positive } \\
\text { Neuropathy, n (\%) }\end{array}$ & $30(39.5)$ & I (2.0) & 3 I (24.6) \\
$\quad$ & & & \\
$\quad$ Negaative & $36(47.4)$ & $45(90.0)$ & 8 I (64.3) \\
$\quad \begin{array}{l}\text { Positive } \\
\text { Nephropathy, n (\%) }\end{array}$ & $40(52.6)$ & $5(10.0)$ & $45(35.7)$ \\
$\quad$ & & & \\
$\quad$ Negaative & $35(46.0)$ & $45(90.0)$ & $80(63.5)$ \\
Positive & $4 I(54.0)$ & $5(10.0)$ & $46(36.5)$ \\
Total, n (\%) & $76(100)$ & $50(100)$ & $126(100)$ \\
\hline
\end{tabular}

Group I: Patients with macroalbuminuria; Group II: Patients with microalbuminuria.

buminuria group, 5 patients $(10.0 \%)$ had nephropathy, with a statistically significant difference $(p<0.05)\left(X^{2}=25.128\right)$ $(p=0.00000$ I) (Table 6).

By analyzing microvascular complications according to the value of albuminuria, it is evident that all three complications are significantly higher in the group of patients with macroalbuminuria. In this group, nephropathy, neuropathy, and retinopathy have a higher incidence when compared to the microalbuminuria group, with complications far less frequently reported in $2-10 \%$ of patients, with a statistically significant difference in all three microvascular complications $(p<0.05)$.

\section{DISCUSSION}

Our retrospective study included 126 subjects with early stage DM2. The study included all patients who were hospitalized at the clinic for a one-year period as a newly diagnosed cases, as well as patients whose diabetes did not last longer than 5 years. Based on gender analysis, we found that women were represented in a larger percentage. This is consistent with the worldwide epidemiological trend of diabetes mellitus. The onset of diabetes mellitus has a genetic predisposition, but is strongly linked to stress and passive lifestyle and is more common in Western Hemi-

Table 5. Ratio of glycemic averages to fasting and $\mathrm{HbAlc}$ in the follow-up groups

\begin{tabular}{|c|c|c|c|c|c|c|}
\hline & \multicolumn{3}{|c|}{ Fasting glucose $(\mathrm{mmol} / \mathrm{L}) \mathrm{t}=0.424 ; p=0.335$} & \multicolumn{3}{|c|}{ HbAIc (\%) t=I.387; $p=0.084$} \\
\hline & Group I $(n=76)$ & Group II $(n=50)$ & Total $(n=126)$ & Group I $(n=76)$ & Group II $(n=50)$ & Total $(n=126)$ \\
\hline Mean & 10.7 & 11.0 & 10.8 & 9.6 & 8.9 & 9.3 \\
\hline SD & 4.6 & 3.9 & 4.3 & 2.9 & 2.2 & 2.6 \\
\hline Minimum & 4.6 & 4.6 & 4.6 & 5.3 & 5.4 & 5.3 \\
\hline Maximum & 24.4 & 25.7 & 25.7 & 16.5 & 13.1 & 16.5 \\
\hline
\end{tabular}

Group I: Patients with macroalbuminuria; Group II: Patients with microalbuminuria; SD: Standard deviation. 
sphere countries. Interestingly, the proportion of people with diabetes in Togo, Africa, is negligible. ${ }^{[8,9]}$ We find that older people are more commonly affected by DM2, which is also consistent with epidemiological indicators in most countries. ${ }^{[10]}$

Analysis of BMI of all patients in our study shows that the highest number of patients is represented in the category $\geq 30 \mathrm{~kg} / \mathrm{m}^{2}$ (obesity), which corresponds to $35.7 \%$ of the respondents. Of the two study groups, the prevalence of obesity was higher in the group of patients with microalbuminuria (44\%) when compared to the group of patients with macroalbuminuria (30.3\%), but without statistical significance $(p>0.05)$. This confirms the well-known fact that people with severe obesity are more likely to contract DM2, as confirmed by several studies. ${ }^{[I]}$

Analysis of the mean fasting glycemic values showed that these values were higher in patients with microalbuminuria $(I I \pm 3.9 \mathrm{mmol} / \mathrm{L})$ when compared with patients with macroalbuminuria $(10.7 \pm 4.6 \mathrm{mmol} / \mathrm{L})$, but with no statistically significant difference $(p>0.05)$. This confirms the standard fact that increased values of pre-meal morning glycaemia is a clear sign of impaired physiological control of glucose metabolism. ${ }^{[12]}$

In $25 \%$ of patients with macroalbuminuria $\mathrm{HbAlc}$ was $\leq 7 \%$ when compared to the group with microalbuminuria where $26 \%$ had $\mathrm{HbAlc} \leq 7 \%$. We can see that both groups had a poor control of DM2. Mean values for $\mathrm{HbAlc}$ in the group of patients with macroalbuminuria were $9.6 \pm 2.9 \%$; whereas, in the group of patients with microalbuminuria, it was $8.9 \pm 2.2 \%(p>0.05)$. The importance of good glycemic control is also shown by the study that found that for every $10 \%$ reduction in $\mathrm{HbAlc}$, the risk of microalbuminuria was reduced by $9 \% .^{[13-15]}$

In our study, albuminuria, among other parameters, is one of the monitored parameters measured by semi-quantitative method, which uses test strips to measure albuminuria above $300 \mathrm{mg}$. Patients were divided into 2 groups according to the presence of albuminuria. Macroalbuminuria was determined by $>200 \mu \mathrm{g} / \mathrm{min}$, that is, $\geq 300 \mathrm{mg} / 24 \mathrm{~h}$ albumin in urine. According to these characteristics, patients were divided into: macroalbuminuria and microalbuminuria group. Of the total population tested, $60.3 \%$ $(n=76)$ had macroalbuminuria and $39.7 \%(n=50)$ had microalbuminuria. Analysis of the mean shows that patients in the total sample had an average age of $66.5 \pm 12.7$ years and that patients with macroalbuminuria were older with an average age of $69.8 \pm \mathrm{II}$.I years when compared to patients with microalbuminuria, where the average age was $6 \mathrm{I} .4 \pm 13.5$ years, with a statistically significant difference $(p<0.05)$. Accordingly, we see a significant association between older age and macroalbuminuria. ${ }^{[16,17]}$

Analysis of the incidence of microvascular complications in DM2 patients, which divided the patients into two groups with respect to albuminuria, shows that all $3 \mathrm{mi}-$ crovascular complications were significantly higher in the examined population of patients with macroalbuminuria $(p<0.05)$. Thus, the relationship between albuminuria and development of microvascular complications is significant. ${ }^{[18]}$

In a study by Al Adsani, I54 patients with DM2 were enrolled. Of these, 102 (66.2\%) were female and 52 (33.8\%) were male, with an average age of $49.1 \pm 10$.I years. In the study, $\mathrm{HbAlc} \leq 7 \%$ was found in $16.3 \%$ and $\mathrm{BMI}>30 \mathrm{~kg} /$ $\mathrm{m}^{2}$ was found in $65.5 \%$ patients. Albuminuria was found in $43.5 \%$ (microalbuminuria $=27.3 \%$, macroalbuminuria $=16.2 \%)$. There was a significantly higher prevalence of albuminuria in patients with retinopathy $(p<0.001)$. Patients with albuminuria had a higher mean $\mathrm{HbAlc}$ value of $10.4 \pm 2.5 \%$ when compared to patients without albuminuria $(8.7 \pm 2.2 \%)$. Albuminuria was also more prevalent in patients with BMI $>30 \mathrm{~kg} / \mathrm{m}^{2}(\mathrm{p}<0.0 \mathrm{I})$. Glycaemia control, $\mathrm{BMI}$, and presence of retinopathy are significantly associated with albuminuria. Comparing the results of our study with those of a study conducted by Al Adsani, the average value of years was higher in our study $(66.5 \pm 12.7$ vs. $49 \pm 10.1$ years), with a lower representation of women in the overall sample (57.9\% vs. $66.2 \%)$. Regarding the incidence of macroalbuminuria in the study population, it was significantly higher in our study $(60.3 \%)$. Similar results in both studies were related to average $\mathrm{HbAlc}$ values, since the study by Al Adsani and our study had elevated $\mathrm{HbAlc}$ values in the group of patients with macroalbuminuria ( $10.4 \pm 2.5$ vs. $9.6 \pm 2.9)$ when compared to those in the group of patients with microalbuminuria $(8.7 \pm 2.2$ vs. $8.8 \pm 2.2$ ). In our study, as well as in the study by Al Adsani study, a significantly higher prevalence of retinopathy was confirmed in the group of patients with macroalbuminuria (39.5\%) when compared with the group with microalbuminuria $(2 \%)(p<0.05){ }^{[19]}$

In another study conducted by Medhat K El Shazly and colleagues on a diabetic population in Kuwait, it was shown that, of the 704 DM2 patients enrolled in the study, 61.6\% had one or more chronic diabetic complications. Retinopathy was reported in $30.7 \%$, neuropathy in $32.1 \%$, and nephropathy in $12.4 \%$ of patients. In our study, the incidences of neuropathy (35.7\%) and nephropathy (36.5\%) were higher, while the prevalence of retinopathy in the study population (24.6\%) was lower than that of the study by Medhat K. El Shazly et al. ${ }^{[20]}$

In a study by Rani PK et al., I4|4 subjects with DM2 were included. The incidence of microalbuminuria was $15.9 \%$ and the incidence of macroalbuminuria was $2.7 \%$. Subjects with macroalbuminuria showed a higher incidence of diabetic retinopathy $(60.5 \%$ vs. $31 \%$ vs. $14.1 \%$; $p<0.01)$ when compared to those with microalbuminuria and normoalbuminuria. The average age of the patients was $56.3 \pm 10$ years. Several clinical parameters, such as age, length of diabetes, and systolic pressure, showed the highest values in subjects with macroalbuminuria, followed by microalbuminuria and normoalbuminuria $(p<0.001)$. Diastolic pressure was higher in the study groups with macroalbuminuria and microalbuminuria when compared with those with normoalbuminuria $(83.8 \pm \mid 2.9$ vs. $84.0 \pm 1 \mid .5$ vs. $81.5 \pm 1 \mid$ I. 
$p=0.05)$. The same was confirmed for HbAlc $(9.0 \pm 2.3$ vs. $9.0 \pm 2.3$ vs. $8.0 \pm 2.1 ; p<0.001) \cdot{ }^{[21]}$

Comparing the results of our study with those of Early PK et al. study, we can conclude that the prevalence of macroalbuminuria in our study is significantly higher $(60.3 \%)$ and this may be due to the smaller sample size of the study $(n=126)$ when compared to the population of Early PK study $(n=14 \mid 4)$. At follow-up (mean time = 21.74 months), it was observed that there was 5.21 microvascular events per 1000 subjects per month. Patients who achieved American Diabetes Association (ADA) goals were 1 I \% less likely to have microvascular complications.

Our study confirmed that macroalbuminuria is present in more than $50 \%$ of patients with early stage DM2 and that risk factors significantly affect the incidence of microvascular complications, as confirmed by other studies. ${ }^{[22]}$

Specifically, microalbuminuria is an indicator of a generalized endothelial lesion, which reflect a general vascular permeability disorder, and is also a marker of elevated cardiovascular morbidity and mortality in patients with DM2. ${ }^{[23]}$

With the current measurement methods in our conditions, patients with existing microalbuminuria are not recognized as individuals at increased risk of developing microvascular complications. Therefore, it is very important to introduce the screening of patients for the presence of microalbuminuria as soon as possible, because timely therapeutic response can significantly prolong the occurrence of microvascular complications.

\section{CONCLUSION}

The incidence of DM2 microvascular complications is on the increase. Early diagnosis and an adequate therapeutic approach is needed to prevent the disability. The presence of macroalbuminuria indicates an already advanced disease. Therefore, it is important to introduce screening for the presence of microalbuminuria in practice, which will identify patients at an increased risk of developing microvascular complications.

Ethics Committee Approval

Approved by the University of Sarajevo, Medical Faculty Ethics Committee (date: 05.09.2015, no: 02-3-I-SA-68815).

Peer-review

Internally peer-reviewed.

Authorship Contributions

Concept: I.S., A.F., I.Sul.; Design: I.S., A.F.; Supervision: I.S., I.Sul., O.S.; Fundings: I.S., A.F., M.T.; Materials: I.S., A.F.; Data: I.S., A.F.; Analysis: A.F., O.S., M.T.; Literature search: I.S., A.F., M.T., O.S.; Writing: I.S., A.F., I.Sul., O.S.; Critical revision: I.S., O.S., I.Sul.

Conflict of Interest

None declared.

\section{REFERENCES}

1. Spurr S, Bally J, Hill P, Gray K, Newman P, Hutton A. Exploring the prevalence of undiagnosed prediabetes, type 2 diabetes mellitus, and risk factors in adolescents: A systematic review. J Pediatr Nurs 2019;50:94-104.

2. Thakur SK, Dhakal SP, Parajuli S, Sah AK, Nepal SP, Paudel BD. Microalbuminuria and Its Risk Factors in Type 2 Diabetic Patients. J Nepal Health Res Counc 2019;17:61-5.

3. Patel Y, Shingare A, Kalita G, Bhandari V. A Clinical Study of Microvascular Complications in Newly Diagnosed Diabetes Mellitus Patients. Indian Journal of Applied Research 2011;4:12-4.

4. American Academy of Ophthalmology. Diabetic Retinopathy. Preferred Practice Pattern 1994.

5. Perkins BA, Bril V. Diabetic neuropathy: a review emphasizing diagnostic methods. Clin Neurophysiol 2003;114.1167-75.

6. Sampath Kumar A, Arun Maiya G, Shastry BA, Vaishali K, Maiya $\mathrm{S}$, Umakanth S. Correlation between basal metabolic rate, visceral fat and insulin resistance among type 2 diabetes mellitus with peripheral neuropathy. Diabetes Metab Syndr 2019;13:344-8.

7. Weidmann P, Schneider M, Bohlen L. Terapeutic efficacy of different antihypertensive drugs in human diabetic nephropathy: an updated meta-analysis. Nephrol Dial Transplant 1995;10:39-45.

8. Sundufu AJ, Bockarie CN, Jacobsen KH. The prevalence of type 2 diabetes in urban Bo, Sierra Leone, and in the 16 countries of the West Africa region. Diabetes Metab Res Rev 2017;33.

9. Holman RR, Paul SK, Bethel MA, Matthews DR, Neil HA. 10-year follow-up of intensive glucose control in type 2 diabetes. $\mathrm{N}$ Engl J Med 2008;359:1577-89.

10. American Diabetes Association, Diagnosis and Classification of Diabetes Mellitus. Diabetes Care 2008;31:S55-S60.

11. Koh-Banerjee P, Wang Y, Hu FB, Spiegelman D, Willett WC, Rimm EB. Changes in body weight and body fat distribution as risk factors for clinical diabetes in US men. Am J Epidemiol 2004;159:1150-9

12. Alvin CP. Diabetes Mellitus: Diagnosis, Classification, and Patophysiology. Harrison's Principles of Internal Medicine. 19th Ed. New York: McGraw-HillEducation; 2015. p. 2399-401.

13. Molyneaux LM, Constantino MI, McGill M, Zilkens R, Yuw DK. Better glycaemic control and risk reduction of diabetic complications in Type 2 Diabetes: Comparison with DCCT. Diabetes Res Clin Pract 1998;42:77-83.

14. Rozing MP, Møller A, Aabenhus R, Siersma V, Rasmussen K, Køster-Rasmussen R. Changes in $\mathrm{HbA1c}$ during the first six years after the diagnosis of Type 2 diabetes mellitus predict long-term microvascular outcomes. PLoS One 2019;14:e0225230.

15. Nakanishi S, Hirukawa H, Shimoda M, Tatsumi F, Kohara K, Obata $\mathrm{A}$, et al. Comparison of HbA1c levels and body mass index for prevention of diabetic kidney disease: A retrospective longitudinal study using outpatient clinical data in Japanese patients with type 2 diabetes mellitus. Diabetes Res Clin Pract 2019;155:107807.

16. Harris MI, Klein R, Welborn TA, Knuiman MW. Onset of NIDDM occurs at least 4-7 $\mathrm{yr}$ before clinical diagnosis. Diabetes Care 1992;15:815-9.

17. Glassock RJ. Is the presence of microalbuminuria a relevant marker of kidney disease? Curr Hypertens Rep 2010;12:364-8.

18. Silva AM, Schaan BD, Signori LU, Plentz RD, Moreno H Jr, Bertoluci MC, et al. Microalbuminuria is associated with impaired arterial and venous endothelium-dependent vasodilation in patients with Type 2 diabetes. J Endocrinol Invest 2010;33:696-700.

19. Al Adsani A. Risk factors associated with albuminuria in $\mathrm{Ku}$ waiti adults with type 2 diabetes. Saudi J. Kodney Dis Transpl 2012;23:860-5. 
20. El-Shazly M, Al Shammer R, Moula AA, Ismail A, Ismail W. Prevalence and factors associated with chronic diabetic complications among patients attending primary health care, a multi-centric Study in Kuwait. Alexandria journal of medicine 2020;46:165-76..

21. Rani PK, Raman R, Gupta A, Pal SS, Kulothungan V, Sharma T. Albuminuria and Diabetic Retinopathy in Type 2 Diabetes Mellitus Sankara Nethralaya Diabetic Retinopathy Epidemiology And Molecular Genetic Study (SN-DREAMS, report 12). Diabetol Metab Syndr 2011;3:9.
22. Lou J, Jing L, Yang H, Qin F, Long W, Shi R. Risk factors for diabetic nephropathy complications in community patients with type 2 diabetes mellitus in Shanghai: Logistic regression and classification tree model analysis. Int J Health Plann Manage 2019;34:1013-24.

23. Orsi E, Solini A, Bonora E, Fondelli C, Trevisan R, Vedovato M, et al; Renal Insufficiency and Cardiovascular Events (RIACE) Study Group. Haemoglobin A1c variability is a strong, independent predictor of all-cause mortality in patients with type 2 diabetes. Diabetes Obes Metab 2018;20:1885-93.

\section{Albüminürili Diabetes Mellitus Tip 2'nin Erken Dönemindeki Mikrovasküler Komplikasyonlarının Sıklığı}

Amaç: Diabetes Mellitus Tip 2 (DM2) değişik derecelerde insülin direnci, bozulmuş insülin sekresyonu ve artmış glikoz üretimi ile karakterizedir. DM2 olan bazı kişilerde nefropati, retinopati ve nöropati gibi daha bir çok komplikasyon vardır. Böbrek yetersizliğinin en erken evresi uzamış mikroalbüminüri ile ortaya çıkar. Çalışmanın amacı DM2 hastalarında en sık görülen mikrovasküler komplikasyonların insidansını belirlemektir.

Gereç ve Yöntem: 2014 yılında muayene edilen 126 hastanın verileri geriye dönük olarak değerlendirildi. Hasta öyküsünden elde edilen anamnez, laboratuvar ve fizik muayene verilerini içeriyordu. Erken evre DM2'li tüm hastalar, mevcut albüminürilerine göre Grup I (makroalbüminürili grup) ve Grup II (mikroalbüminürisi $<300 \mathrm{mg}$ olan grup) olmak üzere iki gruba ayrıldı. Mikrovasküler komplikasyonları değerlendirmek ve çalışılan popülasyonda albüminüri insidansını belirlemek için toplanan verilerin analizi ve istatistiksel çözümlenmesi yapıldı.

Bulgular: Makroalbüminüri prevalansı \%60.3 (76 hasta) idi. Her iki grupta da toplam örneklemde olduğu gibi kadın hasta sıklığı daha yük-

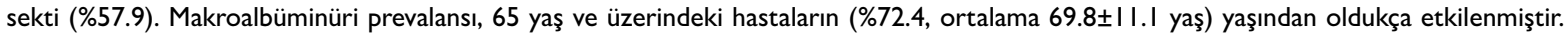
Mikroalbüminürinin, DM2'nin mikrovasküler komplikasyonlarının (retinopati \%39.5, nöropati \%52.6 ve nefropati \%54) gelişiminde son derece önemli bir belirteç olduğu kanıtlanmıştır.

Sonuç: Hasarın önlenmesi için uygun bir terapötik yaklaşımla mikrovasküler komplikasyonların erken evrede teşhisine ihtiyaç vardır. Bu nedenle, mikrovasküler komplikasyon geliştirme riski yüksek olan hastaları belirleyecek olan mikroalbüminürinin saptanmasına ilişkin taramanın uygulamaya başlanması önem taşır.

Anahtar Sözcükler: Diyabet; komplikasyonlar; nefropati; retinopati; nöropati. 